\title{
Carolyne Wright as "Scholar Gipsy"
}

A review of $A$ Change of Maps by Carolyne Wright

(Lost Horse Press, 2006)

Carolyne Wright's latest poetry collection, A Change of Maps, may remind those with keen memories of Matthew Arnold's poem "The Scholar Gipsy," in which a mysterious male figure abandons the safety of Oxford's "dreaming spires" to wander the world in search of truth. Poet and scholar Wright has also wandered the world, both in her life and in this new book. The collection reveals a ship's log of discovery and loss that will resonate especially with women of intellect who navigate the shoals of career and love at home or abroad.

Wright has worked her way across the United States, Latin America, and Asia with an astonishing list of earned scholarships, awards, fellowships, grants and visiting writer posts. With a Ph.D. in English and Creative Writing from Syracuse University, she spent years in India, Bangladesh, and Chile on Fulbright projects and other grants that led to publication of three volumes of translations from Bengali and Spanish poetry. Forthcoming in 2008 from White Pine Press is an anthology of translations, Majestic Nights: Love Poems by Bengali Women. Prior to the current book, a collection of her own poetry with Latin American background called Seasons of Mangoes and Brainfire won the Blue Lynx prize from Eastern Washington University Press, as well as the American Book Award from the Before Columbus Foundation. Wright reveals the strength of her intelligence, energy, and ambition in this present book.

The opening poem, a tour de force abecedarium called "Studies with Miss Bishop," paints a humorous but devastating picture of an aging, financially pressed poet-in-residence, Elizabeth Bishop, who reluctantly presides over a "dazed / clutch of undergraduates." Adopting the formalism Bishop imperiously demanded of her young students, Wright crafts twenty-six couplets that not only begin with the requisite $A B C s$ and end with subtle slant rhymes, but also entertain the reader with colorful vignettes and playful language. By 
the letter $S$, though, the poem has skillfully metamorphosed into a double-edged pathos:

So much I didn't know that distracted season-

she staggered past me, unseeing, one April afternoon

toward campus, clumsy in her Minnie Mouse black shoes, timid wind twisting through the Sitka spruce

under which she stopped to gasp, her breath rasping in uncanny panic. How did she recover, masking in

vertiginous dignity her retreat? I didn't dare

venture from cover, volunteer my arm. I watched her...

First close up, then from afar during succeeding years, the younger poet observes how the peripatetic Bishop circulated from one college to another, ironically foreshadowing Wright's own gipsy scholarship. The poem arrives at $\mathrm{Z}$ with an answer to friends who question how she can prove her study under the famous Elizabeth Bishop without the documentation of "xeroxed handouts before xerography." Wright retorts, with a wry, oxymoronic phrase from one of Bishop's poems: "My evidence? a life's uneasy parallels: a new / zip code every year, no tenure, child, or lover going spousal. Still/ Zen's empty bowl runneth over. Awful? Yes! But cheerful!"

Wright's tone of awful-but-cheerful adds spice to what could otherwise seem a lonely journey through baffling physical and emotional geography. In the language of cartography, the title poem, "A Change of Maps," characterizes the poet's-and other humans'-experience of dizzying change in a time of cosmic and cybernetic exploration. With an ability to turn a phrase on a dime, Wright steers her readers past ancient maps that can't explain "how such charts voyaged into the New World / of our luggage" into "microchips shrinking our wildest dreams." She intensifies this disorientation in another poem, "Unfinished Country," with a complex repetition of words such as moon, truth, lamps, nighthawks that raise the poem to heights of lyric beauty: 
"How high the moon?" we talked around ourselves as air and ocean switched polarities

over the heart's unfinished country. The truthwe hesitated, lost ourselves in lamplight

while nighthawks circled, crying for direction.

The poems continue with striking variation from passionate lyricism, to edgy satire, to near-comic relief as Wright dramatizes, for example, a picaresque take on the zeitgeist of the Sixties in "Bildungsgedicht," starring a sixteen-year-old minx fascinated with "Johnny Dee, the wicked-thin, mop-topped rock singer." After a summer fling, she's jilted and "sobbing by the Orange Julius machine." But she ends triumphantly by telling her worried mother "the truth" and announcing, I'm starting a poem. Carolyne Wright is still writing that poem, with ever more vigor and poignancy.

A rogue's gallery of lost or faithless lovers flickers in and out of the poems as the wanderer searches for a companion who is "true north"-now found, judging from the book's dedication page. She avoids the confessional mode by cloaking episodes in mystery with an incognito "we" instead of the first person singular. Still, the poetry strongly reveals a woman's search for love, as well as a scholar's parallel search for independence and intellectual fulfillment. Unlike Matthew Arnold's seeker, she does not squelch her "quick inventive brain" or renounce normal human company while awaiting "the spark of Heaven to fall."

The second half of $A$ Change of Maps bears a subtitle, "The Custody of the Eyes," suggested by St. Bonaventure's admonition for nuns against "all inordinate glancing about." Throughout this second section, the work seems to deepen in seriousness and grow even richer in virtuosity. Three extraordinary sestinas use their prescribed form to create the modern gipsy's tidal sense of flux. Another striking poem with a timely subject, "Darwin's House at Downe (Closed Fridays)," presents a flowing set of twenty-one three-line stanzas to describe an attempted visit to the evolutionist's house. The poem becomes a parable for today's globalized human species: 
The laboratory in ruins, the big elms gone, we drove off past the NO ADMITTANCE doors

back to our childless, fin de siècle rooms, wondering what would become of our kind-taking the fixed laws

so lightly, rushing in ever-smaller cars down the widening flow of motorway, as we matched names on the maps

to houses older than our country, as if scraps of someone else's history could make us whole: a species

teetering at the top of its form, where evolution stopped a moment. Then moved on.

The book builds tension toward its penultimate poem, "Clairvoyant's Reading," where the reader falls into the hands of an ominous uber-gipsy. Lyric incantation mixes icons of history with vivid fragments of all six senses:

Unlock the Sphinx, she tells me, there's

a yellow scent for miles.

Roman sculptures cluster on the hills.

The Archer draws his crossbow

over the observatory dome-

At the field's edge, an Arab pony

paws the mustard flowers. Pyramids

glisten in blood-begotten light.

After four more haunting stanzas, the reader, as if under a spell, almost fears to turn the key in spite of the sibylline promise, "What is behind you/ is forgiven. Now go, unlock the Sphinx."

The final poem, "The Custody of the Eyes," pulls back from the abyss to close with wit, self-deprecation, and an entertaining riff 
on ophthalmology - the speaker's childhood amblyopia requiring a "Captain Kidd patch"; a tasteless statue of St. Lucy carrying her eyeballs on a trencher; and an aquarium's young flounders with upside-down eyes migrating. She ends this awful-but-cheerful recitation with a kind of hard-won peace, as if weary of her gipsy desire to travel everywhere, see everything:

I lay me down,

to dream of the lofty Madonna

of my assumptions. I take off my spectacles,

cross the side-arms, turn out the light.

Sisters, I pray, let your glances

trespass in my direction.

I renounce old Argus and his many eyes.

"Custody of the Eyes," collected as a series with other related poems, won the prestigious Pablo Neruda prize awarded by Mark Strand in an annual competition sponsored by Nimrod literary magazine. Coinciding with Strand's idea in his book, The Continuous Life of Poetry, Wright uses poetry as a means of continuity, even survival, in a time of changing maps and shaken trust. With Elizabeth Bishop, Wright shares an easy, sophisticated display of language and a vivid obsession with geography as metaphor. With Matthew Arnold, it's the will-o'-the wisp search for answers that propels "The Scholar Gipsy." But in spite of these kinships, Wright is no clone of Arnold, Bishop, or Strand. She is sui generis, one of a kind, who writes brilliantly with her eyes on history, literature, and the stars. She also looks through the microscope of self and takes what she sees with a dash of salt, as well as a stab of the heart. 